\title{
PROGRAM BIMBINGAN BACA TULIS AL QUR'AN \\ BAGI ANAK BERKEBUTUHAN KHUSUS (AUTIS) \\ DI SD AL AZZAM KETILENG SEMARANG
}

\author{
KHOLFAN ZUBAIR TAQO SIDQI \\ Dosen Prodi PAI/Fakultas Agama Islam, Universitas Wahid Hasyim Semarang \\ Email:pan_taqo@yahoo.co.id
}

\begin{abstract}
This article discusses guidance program Read Qur'an for children with special needs. The results show that a number of conditions (multi / many factors) affect the brain development of autistic children that occurred since the age of 6 months in the womb and continue in life, where genetic factors (heredity) is a very influential factor. These brain development disorders cause problems with language skills, cognitive ability (comprehension), social interaction ability, and adaptive function, hence this causes the increasing age of a child will lead to greater gap / different abilities compared with other children as peer age, so the more visible differences with children peer age / his age. All of these things can be clearly seen before the child is 3 (three) years old, and the age will be more visible.
\end{abstract}

Keywords: Guidance to Read Al Qur'an, Autism

\section{A. Pendahuluan}

Autisme adalah gangguan perkembangan nerobiologi yang berat yang terjadi pada anak sehingga menimbulkan masalah pada anak untuk berkomunikasi dan berelasi (berhubungan) dengan lingkungannya. Penyandang autisme tidak dapat berhubungan dengan orang lain secara berarti, serta kemampuannya untuk membangun hubungan dengan orang lain terganggu karena masalah ketidak mampuannya untuk berkomunikasi dan untuk mengerti apa yang dimaksud oleh orang lain. Tanda-tanda/gejala ini sudah nampak jelas sebelum anak berusia 3 tahun, dan kemudian berlanjut sampai dewasa jika tidak dilakukan intervensi yang tepat. Penyandang autisme memiliki gangguan pada interaksi sosial, komunikasi, imajinasi, serta pola perilaku yang repetitif (berulang-ulang), dan resistensi (tidak mudah mengikuti/menyesuaikan) terhadap perubahan pada rutinitas. Gangguan pada interaksi sosial ini menyebabkan mereka terlihat aneh dan berbeda dengan orang/anak lain. Gangguan pada komunikasi yaitu terjadi pada komunikasi verbal (lisan/dengan kata- 
kata) maupun non verbal (tidak mengerti arti dari gerak tubuh, ekspresi wajah, dan nada/warna/intonasi suara). Gangguan pada imajinasi ini menyebabkan anak kesulitan dalam hal aktivitas dan bermain, sehingga bermain dan beraktivitas berbeda dengan orang/anak lain, misalnya hanya mencontoh dan mengikuti suatu hal secara kaku dan berulang-ulang.

Hasil penelitian menunjukkan bahwa sejumlah kondisi (multi/banyak faktor) mempengaruhi perkembangan otak anak autistik yang tejadi sejak usia 6 bulan dalam kandungan dan terus berlanjut dalam kehidupannya, dimana faktor genetik (keturunan) merupakan faktor yang sangat berpengaruh. Gangguan perkembangan otak ini menyebabkan terjadinya gangguan / masalah pada kemampuan bahasa, kemampuan kognitif (pemahaman), kemampuan interaksi sosial, dan fungsi adaptifnya, maka hal ini menyebabkan semakin bertambahnya usia seorang anak maka akan menyebabkan semakin besarnya kesenjangan / perbedaan kemampuan - kemampuan tersebut dibandingkan dengan anak lain sepantarannya/seumurnya, sehingga semakin terlihat perbedaannya dengan anak sepantarannya/seumurnya. Semua hal ini dapat jelas terlihat sebelum anak berusia 3 (tiga) tahun, dan semakin bertambah umurnya akan semakin jelas terlihat.

\section{B. Rumusan Masalah}

Bagaimanakah program Bimbingan Baca Tulis Al Qur'An Bagi Anak Berkebutuhan Khusus(Autis) $\mathrm{Di} \quad \mathrm{Sd} \quad \mathrm{Al}$ Azzam Ketileng Semarang?

\section{Kerangka Berpikir}

\section{Klasifikasi Anak Autis}

Menurut Yatim (2002) dalam YAI, anak autis dapat dikelompokkan menjadi tiga yaitu:

a. Autisme persepsi: dianggap autisme yang asli kerana kelainan sudah timbul sebelum lahir. Ketidak mampuan anak berbahasa termasuk pada penyimpangan reaksi terhadap rangsangan dari luar, begitu juga kemampuan anak bekerjasama dengan orang lain, sehingga anak bersikap masa bodoh / cuek.

b. Autisme reaksi: terjadi karena beberapa permasalahan yang menimbulkan kecemasan seperti orang tua meninggal, sakit berat, pindah rumah/sekolah dan sebagainya. Autisme ini akan 
memuncukan gerakan-gerakan tertentu berulang -ulang, kadangkadang disertai kejang-kejang. Gejala ini muncul pada usia lebih besar enam sampai tujuh tahun sebelum anak memasuki tahapan berfikir logis.

c. Autisme yang timbul kemudian: terjadi setelah anak agak besar, dikarenakan kelainan jaringan otak yang terjadi setelah anak lahir. Hal ini akan mempersulit dalam hal pemberian pelatihan dan pelayanan pendidikan untuk mengubah perilakunya yang sudah melekat.

\section{Penyebab Anak Autisme}

Beberapa teori terakhir mengatakan bahwa faktor genetika memegang peranan penting pada terjadinya autistik. Bayi kembar satu telur akan mengalami gangguan autistik yang mirip dengan saudara kembarnya. Juga ditemukan beberapa anak dalam satu keluarga atau dalam satu keluarga besar mengalami gangguan yang sama. Selain itu pengaruh virus seperti rubella, toxo, herpes, jamur, nutrisi yang buruk; pendarahan; keracunan makanan; dan sebagainya pada kehamilan dapat menghambat pertumbuhan sel otak yang dapat menyebabkan funsi otak bayi yang dikandung terganggu terutama fungsi pemahaman, komunikasi dan interaksi. Akhir-akhir ini dari penelitian terungkap juga hubungan antara gangguan pencernaan dan gejala autistik. Ternyata lebih dari $60 \%$ penyandang autistik ini mempunyai sistem pencernaan yang kurang sempurna. Makanan tersebut berupa susu sapi (casein) dan tepung terigu (gluten) yang tidak tercena dengan sempurna. Protein dari kedua makanan ini tidak semuanya berubah manjadi asam amino tapi juga menjadi peptida, suatu bentuk rantai pendek asam amino yang seharusnya dibuang lewat urin . ternyata pada penyandang autistik, peptida ini diserap kembali oleh tubuh, masuk kedalam aliran darah, masuk ke otak dan mebuat fungsi otak terganggu. Fungsi otak yang terkena biasanya adalah fungsi kognitif, reseptif, atensi dan perilaku.

Biasanya pasien autis mengalami kehilangan kemampuan sistem imunitas sehingga terjadi inflamatory. Cytokine diproduksi secara berlebihan dalam darah putih, kadarnya meningkat dan hal itu menyebabkan terjadinya abnormal neurology. Percobaan telah dilakukan terhadap pengaruh asupan gluten dan kasein ke 
dalam makanan yang akan dikonsumsi oleh anak normal dibandingkan dengan anak penderita autis. Dalam kedua darah anak tersebut dianalisa kandungan cytokine-nya, ternyata kandungan cytokine dalam darah penderita autistik meningkat jauh lebih tinggi daripada darah anak normal. Peningkatan cytokine tersebut dapat menjadi penyebab secara genetik yang kelak akan menyebabkan timbulnya penyakit autisme.

Reaksi Opioid adalah suatu reaksi yang paling merusak. Hal itu biasanya diakibatkan oleh terjadinya kebocoran usus (leaky guts). Sekitar $50 \%$ pasien autis mengalami kebocoran usus sehingga terjadi ketidakseimbangan flora usus. Peptida hasil pemecahan gluten atau kasein dikirim ke otak dan kemudian ditangkap reseptor opioid. Hal ini menyebabkan autisme, kondisi reaksi opioid menyerupai kondisi seperti baru mengkonsumsi obat-obatan serupa morphin atau heroin. Pada saat dalam kandungan ternyata penderita autis mengalami peningkatan jumlah protein dalam darah, yaitu 3X lebih besar dari anak yang kemudian terlahir normal dan setelah kelahiran terus meningkat hingga mencapai 10X normal. Pada anak normal tidak terjadi mengalami kenaikan. Peningkatan jumlah protein darah yang abnormal pada penderita ini dapat mengacaukan proses migrasi sel normal atau bahkan mematikan sel selama masa perkembangan sistem saraf berlangsung. Perlu diingat bahwa pertumbuhan saraf selama embrio penting untuk membentuk formasi sistem saraf pusat dan sel otak yang baru. Selain faktor diatas umur ayah berperan terhadap terjadinya autisme pada anak. Menurut sebuah artikel di “Associated Press, 5 September 2006, pria yang menjadi ayah pada umur 40 tahun atau lebih berisiko lebih tinggi untuk mempunyai anak autistik. Suatu penelitian di Israel membuat berita yang heboh di Amerika dan Inggris. 130.000 Anak Yahudi dari Israel yang lahir pada sekitar tahun 1980 diikut sertakan dalam penelitian ini. Anak-anak yang dilahirkan dari ayah yang lebih tua, enam kali lebih banyak menderita gangguan autisme dan sejenisnya, daripada anak-anak yang dilahirkan dari ayah yang lebih muda. Sedangkan dibandingkan dengan ayah yang berumur antara 30-39 tahun, frekwensi gangguan pada anaknya satu setengah kali lebih tinggi. Umur ibu ternyata malah tidak ada relevansinya. 


\section{Cara Mengenali Gejala Autisme Pada Anak}

Sampai sekarang belum ada alat untuk mendiagnosis pasti autis pada bayi. Saat ini beberapa ahli melakukan screening test mulai bayi umur empat bulan. Pada usia empat bulan orangtua dianjurkan untuk mengobservasi anaknya meliputi:

a. Reaksi terhadap warna terang dan dapat mengikuti objek yang digerakkan.

b. Menoleh ke arah sumber suara.

c. Reaksi menatap muka terhadap wajah seseorang.

d. Tersenyum bila kita tersenyum padanya.

Pada usia 12 bulan bayi perlu diwaspadai mungkin adanya gejala autis seperti:

a. Tidak ada kontak mata.

b. Tidak bisa menunjuk objek tertentu.

c. Tidak bisa memberikan barang kepada orang.

d. Tidak mengerti bila namanya dipanggil.

e. Tidak bisa berkomunikasi babble (mengatakan "pa pa", "ma ma", "da da").

Bila ditemukan gejala ini perlu konsultasi ke dokter spesialis anak, mungkin kelainan ini merupakan gejala dini autis. Memastikan diagnose autis perlu diamati dan dievaluasi lebih lanjut.

\section{Autis bukan penyakit dan tidak menular}

Pemahaman soal autisme memang masih perlu disosialisasikan kepada masyarakat. Banyak yang menganggap bahwa autisme merupakan suatu penyakit dan dianggap dapat menular kepada orang lain. Padahal tidak seperti itu. Duta Masyarakat Peduli Autis Indonesia (MPATI), dr Lula Kamal mengatakan bahwa banyak yang berpandangan bahwa autisme adalah penyakit dan dapat menular. Padahal autisme hanyalah gangguan tumbuh kembang yang menyebabkan anak tidak dapat fokus terhadap sesuatu. "Autisme adalah gangguan tumbuh kembang sehingga membutuhkan penanganan khusus, dan autisme itu bukan penyakit dan tidak menular lho," Ujar dr Lula, ditemui di Senayan City dan ditulis Kamis (23/10/2014). Karena bukan penyakit dan tidak menular, secara teori anak autis boleh saja melakukan donor darah jika sudah memenuhi syarat berusia 17 tahun, berat badan di atas $45 \mathrm{~kg}$ dan memiliki kadar hemoglobin yang cukup. Bahkan dr Shalimar, Ketua Unit Donor Darah PMI DKI Jakarta mengatakan bahwa 
donor darah dapat dilakukan siapapun termasuk penyandang masalah tumbuh kembang seperti autis. "Jika sudah 17 tahun dan memenuhi syarat menjadi donor, anak autis boleh kok buat donor selama sehat dan tidak ada kelainan di darahnya, tapikan anak autis sangat sulit beradaptasi dengan orang baru sehingga akan membutuhkan persiapan yang khusus kan, lagi pula saya belum pernah menemui anak autis yang donor darah," tutur dr Shalimar. Di tempat yang sama, Dunya Mugijanto yang bertindak sebagai Kepala Publik Relation Yayasan Masyarakat Peduli Autis Indonesia (MPATI) mengatakakan bahwa anak autis seharusnya diberikan perhatian lebih. Misalnya dengan mengadakan hari ramah autis sehingga masyarakat lebih paham terhadap autisme. "Anak autis harus dapat ekstra perhatian karena mereka kan berbeda dengn anak biasa. Dulu kita (MPATI) punya hari ramah autis waktu zamannya pak Jokowi, nah sekarang kita lagi lobi lagi sama pak Ahok biar hari ramah autis diadakan lagi, tujuan utamanya biar kita bisa mengampanyekan tentang apa itu autis," pungkasnya.

\section{Terapi anak Autis}

Terapi pada dasarnya perlu diberikan untuk membangun kondisi yang lebih baik. Terapi juga harus rutin dilakukan agar apa yang menjadi kekurangan anak dapat dipenuhi secara bertahap. Terapi juga harus diberikan sedini mungkin sebelum anak berusia 5 tahun. Sebab, perkembangan pesat otak anak umumnya terjadi pada usia sebelum 5 tahun, tepatnya puncak pada usia 2-3 tahun. Beberapa terapi yang ditawarkan oleh para ahli adalah :

\section{a. Terapi Biomedik}

Terapi biomedik dikembangkan oleh kelompok dokter yang tergabung dalam Defeat Autism Now. Pada terapi ini difokuskan pada pembersihan fungsifungsi abnormal pada otak. Dengan terapi ini diharapkan fungsi susunan saraf pusat bisa bekerja lebih baik sehingga gejala autism berkurang atau bahkan menghilang. Obat-obatan juga digunakan untuk penyandang autism, namun harus dengan pengawasan dokter spesialis yang lebih memahami dan mempelajari autism. Terapi biomedik melengkapi terapi lainnya dengan memperbaiki dari dalam (biomedis). Selain didukung oleh terapi dari dalam dan luar diri agar mengalami kemajuan yang cukup bagus.

\section{b. Terapi Okupasi}

Terapi okupasi berguna untuk melatih otot-otot halus anak. Menurut 
penelitian, hamper semua kasus anak autistic mempunyai keterlambatan dalam perkembangan motorik halus. Gerak-geriknya sangat kaku dan kasar, mereka kesulitan untuk memegang benda dengan cara yang benar, kesulitan untuk memegang sendok dan menyuapkan makanan ke dalam mulutnya,dsb. Dengan terapi ini anak akan dilatih untuk membuat semua otot dalam tubuhnya berfungsi dengan tepat.

\section{c. Terapi Integrasi Sensoris}

Terapi ini berguna meningkatkan kematangan susunan saraf pusat, sehingga lebih mampu untuk memperbaiki struktur dan fungsinya. Aktivitas ini merangsang koneksi sinaptik yang lebih kompleks, dengan demikian bisa meningkatkan kapasitas untuk belajar.

\section{d. Terapi Bermain}

Terapi bermain adalah pemanfaatan pola permainan sebagai media yang efektif dari terapis, melalui kebebasan eksplorasi dan ekspresi diri. Pada terapi ini, terapis bermain menggunakan kekuatan terapiutik permainan untuk membantu klien menyelesaikan kesulitan-kesulitan psikososial dan mencapai pertumbuhan, perkembangan yang optimal.

\section{e. Terapi Perilaku}

Terapi ini memfokuskan penanganan pada pemberian reinforcement positif setiap kali anak berespons benar sesuai intruksi yang diberikan. Tidak ada punishment dalam terapi ini, akan tetapi bila anak menjawab salah akan mendapatkan reinforcement positif yang ia sukai. Terapi ini digunakan untuk meningkatkan pemahaman dan kepatuhan anak pada aturan. Dari terapi ini hasil yang didapatkan signifikan bila mampu diterapkan secara intensif.

\section{f. Terapi Fisik}

Beberapa penyandang autism memiliki gangguan perkembangan dalam motorik kasarnya. Kadang tonus ototnya lembek sehingga jalannya kurang kuat. Keseimbangan tubuhnya juga kurang bagus. Fisioterapi dan terapi integrasi sensoris akan sangat banyak menolong untuk menguatkan otot-otot dan memperbaiki keseimbangan tubuh anak.

\section{g. Terapi Wicara}

Hampir semua anak dengan autism mempunyai kesulitan dalam bicara dan berbahasa. Kadang-kadang bicaranya cukup berkembang, namun mereka tidak mampu untuk memakai kemampuan bicaranya untuk 
berkomunikasi/berinteraksi dengan orang lain.

\section{h. Terapi Musik}

Terapi music menurut Canadian Association for Music Therapy (2002) adalah penggunaan music untuk membantu integrasi fisik, psikologis, dan emosi individu, serta untuk treatment penyakit atau ketidakmampuan. Sedangkan menurut American Music Therapy Association (2002) terapi music adalah semacam terapi yang menggunakan music yang bersifat terapi unik guna meningkatkan fungsi perilaku, social, psikologis, komunikasi, fisik, sensorik motorik dan kognitif.

\section{i. Terapi Perkembangan}

Terapi ini didasari oleh adanya keadaan bahwa anak dengan autis melewatkan atau kurang sedikit bahkan banyak sekali kemampuan bersosialisasi.yang termasuk terapi perkembangan misalnya Floortime, dilakukan oleh orang tua untuk membantu melakukan interaksi dan kemampuan bicara.

\section{j. Terapi Visual}

Individu autistic lebih mudah belajar dengan melihat. Hal inilah yang kemudian dipakai untuk mengembangkan metode belajar berkomunikasi melalui gambar- gambar. Beberapa video games bisa juga dipakai untuk mengembangkan keterampilan komunikasi.

\section{k. Terapi Medikamentosa}

Disebut juga terapi obat-obatan. Terapi ini dilakukan dengan pemberian obat-obatan oleh dokter yang berwenang. Para penyandang jangan diberi sembarang obat, tapi obat harus diberikan bila timbul indikasi kuat. Gejala yang sebaiknya dihilangkan dengan obat : hiperaktivitas yang hebat, menyakiti diri sendiri, menyakiti orang lain (agresif), merusak (destruktif), dan gangguan tidur.

\section{l. Terapi Melalui Makanan}

Terapi melalui makanan diberikan untuk anak-anak dengan masalah alergi makanan tertentu. Di sisi lain, ada bebrapa makanan yang mengandung zat yang dapat memperberat gejala autis pada anak. Dalam terapi ini diberikan solusi tepat bagi para orang tua untuk menyiasati menu yang cocok dan sesuai bagi putra-putrinya sesuai dengan petunjuk ahli mengenai gizi makanan.

Anak-anak yang menderita autism tampil seolah-olah mereka terbelenggu oleh pikiran mereka sendiri, sebab mereka tidak dapat mempelajari bahasa, atau keterampilan sosial yang 
dibutuhkan dilingkungannya. Anak anak autis pada tahun ke dua dari kehidupan mereka biasanya kehilangan kemampuan untuk berinteraksi dengan orang-orang dilingkungannya dan tidak berbicara, atau menggunakan bahasa, walaupun banyak diantara mereka mempunyai intelejensi yang normal. "Anak Autis lebih suka menyendiri dan memiliki kegemaran dengan satu benda". (Autisme pada anak: Dr.dr.Y.Handojo, MPH). Penderita autis disebabkan oleh penyakit atau luka didaerah daerah tertentu diotak (perkembangan otak tidak normal), polusi lingkungan oleh timbal, alumunium dan air raksa, disfungsi imunulogi, gangguan masa kehamilan serta abnormalitas sistem gastrointernal (pencernaan), namun secara umum belum ada kesepakan internasional.

\section{Metode penelitian}

\section{Jenis Penelitian}

Jenis penelitian ini adalah penelitian lapangan ( Field Research) yaitu penelitian dengan cara terjun langsung ke lokasi penelitian dan partisipatori studi, yaitu pengamatan langsung yang melibatkan peneliti di dalamnya.

${ }^{1} \mathrm{P}$ Joko Subagyo, Metodologi penelitian teori dan praktek ( Jakarta, Rhineka Cipta, 1991),hal. 109.
Metode yang digunakan adalah metode deskriptif kualitatif, menggambarkan keadaan dengan apa adanya, dengan data yang didapat nonkuantitatif statistik. Pendekatannya yaitu dengan Peadagogis Psikologis/ ilmu pendidikan dan psikologi agama. Dari sudut psikologi bahwa nilai-nilai pendidikan Islam peserta didik dipengaruhi oleh berbagai faktor, maka perlu diarahkan kepada pembentukan perilaku dan watak yang baik, yaitu dengan kegiatan yang tepat.

2. Penentuan Subyek Penelitian

Subyek penelitian adalah orang atau siapa saja yang menjadi sumber data dalam penelitian. ${ }^{2}$ Dalam hal ini yang menjadi subyek penelitian adalah anak - anak di SD Al Azzam Semarang

3. Metode Pengumpulan Data

a. Metode Observasi

Penelitian yang diadakan dengan cara mengadakan pengamatan terhadap obyek baik secara langsung atau tidak langsung. ${ }^{3}$ Metode ini digunakan untuk memperoleh data tentang keadaan geografis, keadaan sekolah tempat penelitian, selanjutnya

\footnotetext{
${ }^{2}$ Suharsimi Arikunto, Prosedur Penelitian

Praktek ( Jakarta, Bina Aksara, 1989 ), hal.114

${ }^{3}$ Ibid, hal.91.
} 
guru dan peserta didik.

b. Metode Wawancara

Pertemuan langsung dengan nara sumber, secara berulang-ulang untuk mendapatkan berbagai data ataupun penjelasan yang utuh dan mendalam darinya. Oleh karena itu aplikasi dari wawancara mendalam tidak bersifat kaku atau terstruktur, bahkan sifatnya lebih terbuka.

c. Metode Dokumentasi

Mencari data mengenai hal-hal atau variable yang berupa cacatan transaksi, buku, surat kabar, majalah, prasasti, notulen rapat, agenda. Metode ini Penulis gunakan untuk menghimpun data dokumenter, seperti intensitas kejadian bencana, buku berkaitan dengan siaga bencana, dsb.

\section{Metode Analisis Data}

Untuk menganalisa data dalam penelitian ini penulis menggunakan analisa non statistik / analisa kualitatif. Metode ini digunakan untuk menganalisa / menginterpretasikan data yang berupa fakta-fakta dari hasil penelitian yang tidak berwujud angka. Penulis akan melakukan interpretasi terhadap data-data yang diperoleh dari penelitian yang diwujudkan dengan uraian-uraian berbentuk kalimat sehingga akhirnya ditarik ke dalam suatu kesimpulan. Langkah-langkah analisa data ini adalah :

a. Langkah Deskriptif, menggambarkan sesuatu hal apa adanya

b. Langkah Interpretatif, menafsirkan atau memperkirakan

c. Langkah Komparatif, membandingkan data-data yang diperoleh

d. Pengambilan keputusan atau menarik kesimpulan ${ }^{4}$

E. Pembahasan

E.1. Pelaksanaan Bimbingan baca tulis Al Qur'an bagi Anak Berkebutuhan Khusus ( Autis)

Pendidikan bagi anak autis tidak sama dengan anak biasa. Kurikulum yang disiapkan tentu juga tidak sama dan sangat individual. Di Indonesia semua hal yang berkaitan dengan pembelajaran untuk kanak-kanak autis berpedoman pada Badan Standar Nasional Pendidikan (BSNP). Namun demikian, dinas pendidikan memberikan kebebasan kepada masing-masing sekolah untuk

${ }^{4}$ DudungAbdurohman, Pengantar Metode Penelitian, (Yogyakarta, Galang Press 2000) hal.63. 
menentukan kurikulum bagi penyandang autis (Eko Djatmiko Sukarso, 2010), ini dikeranakan setiap sekolah memiliki kebutuhan yang berbeza dalam mendidik penyandang autis. Kurikulum autis harus dibuat berbeza-beza untuk setiap individu, mengingat setiap anak yang butuh belajar komunikasi dengan intensif ada yang perlu belajar bagaimana mengurus dirinya sendiri dan ada juga yang hanya perlu fokus pada masalah akademik (Dyah Puspita, 2011). Penentuan kurikulum tiap-tiap anak autis bergantung dari assessment (penilaian) awal yang dilakukan pra sekolah menerima anak autis baru (dini yusuf, 2011).

\section{a. Metode Pendidikan Islam}

Memberikan pendidikan Islam kepada anak perlu menggunakan kepelbagaian teknik yang berturusan contohnya dengan memberikan pemahaman jelas, tepat, pengajaran dan peringatan supaya akidah anak bertapak kukuh dalam jiwa mereka, sama ada anak itu normal ataupun autis. Dalam proses pendidikan Islam, metode juga mempunyai kedudukan yang sangat penting dalam mencapai tujuan.

\section{b. Dasar Metode Pendidian Islam}

Penerapan metode pendidikan Islam menyangkut permasalahan individual atau sosial peserta didik dan pendidik itu sendiri. Untuk itu pendidik harus memperhatikan dasar-dasar umum metode pendidikan Islam. Sebab metode pendidikan merupakan sarana atau jalan menuju tujuan pendidikan, sehingga jalan yang di tempuh oleh pendidik haruslah mengacu pada dasar-dasar metode pendidikan tersebut. Ada empat dasar metode pendidikan Islam, diantaranya ialah dasar agamis, biologis, psikologis dan sosiologis (Rayulis dan Syamsul Nizar, 2009).

1.) Dasar agamis, maksudnya bahawa metode yang digunakan dalam pendidikan Islam haruslah berdasarkan agama. Sedang agama Islam merujuk kepada alQur'an dan Hadist. Oleh kerana itu, dalam pelaksanaan metode yang di guna pakai oleh pendidik hendaknya di sesuaikan dengan al-Qur' an dan Hadist.

2). Dasar biologis, perkembangan biologis manusia mempunyai pengaruh dalam perkembangan intelektualnya. Semakin baik perkembangan biologis seseorang, maka dengan sendirinya makin meningkat pula daya intelektualnya. Untuk itu, dalam menggunakan metode pendidikan 
Islam seorang guru harus memperhatikan perkembangan biologis peserta didik.

3). Dasar psikologis, perkembangan dan kondisi psikoogis peserta didik akan memberi pengaruh yang sangat besar terhadap penerimaan nilai pendidikan dan pengetahuan yang di laksanakan. Dalam kondisi labil, pemberian ilmu pengetahuan akan berjalan tidak sesuai dengan yang di harapkan. Kerana demikian metode pendidikan Islam baru dapat diterapkan secara efektif apabila di dasarkan pada perkembangan dan kondisi psikologis peserta didiknya.

4). Dasar sosilogis, saat pembelajaran berlangsung ada interaksi antara peserta didik dengan peserta didik yang lain dan interaksi antara pendidik dengan peserta didik, atas dasar ini, maka pengguna metode dalam pendidikan Islam harus memperhatikan dasar sosiologis.

Keempat dasar diatas merupakan satu kesatuan yang tidak dapat dipisahkan dan harus diperhatikan oleh para pengguna metode pendidikan Islam agar tercapainya tujuan pendidikan Islam. Ada banyak metode dalam pendidikan Islam, diantaranya seperti metode ceramah, tanya jawab, diskusi, pemberian tugas, demontrasi, eksperimen, amsal atau perupamaan, targhib dan tarhib dan metode pengulangan (Takrir). Kalaupun metode ini biasa di gunakan bagi mendidik anak normal, namun metode-metode ini ada yang sesuai dengan anak autis.

\section{E.2. Pengertian baca tulis Al- Qur'an}

Secara etimologi kata "baca" adalah bentuk kata benda dari kata kerja "membaca" dan "tulis" adalah bentuk kata benda dari kata kerja "menulis". menurut kamus umum bahasa Indonesia, membaca diartikan melihat tulisan dan mengerti atau dapat melisankan apa yang tertulis itu (Powerwadarminta, 1976:1058). sementara menulis diartikan membuat huruf atau angka, melahirkan, pikiran atau gagasan (Poerwadarminta, 1976:1058). Melahirkan pikiran atau perasaan tidak dapat dilukiskan tanpa membaca sesuatu yang menjadi sasaran atau objek tulisan.

Membaca dalam hal berkenaan dengan al-Qur'an dapat diartikan melihat tulisan yang terdapat pada al-Qur'an dan melisankannya. Akan tetapi membaca alQur'an bukan hanya melisankan huruf, tetapi mengerti apa yang diucapkan, 
meresapi isinya, serta mengamalkannya. Imam Al-Ghazali mengungkapkan sebagai berikut: "Adapun kalau menggerakan lidah saja, maa akan makin sedikit yang diperolehnya, karena yang dinamakan membaca harus ada perpaduan antara lidah, akal dan hati. Pekerjaan lidah adalah membenarkan bunyi huruf dengan jalan tartil (membaca perlahan-lahan dan teratur). Pekerjaan akal mengenang makna dan tujuannya, sedangkan pekerjaan hati adalah menerima nasehat dan peringatan dari apa yang dipahaminya. (AndrianFITK.pdf.secured. 2009:18)

Membaca adalah suatu kegiatan yang melibatkan seluruh struktur mental manusia sebagai seorang individu. Meski demikian, bukan berarti membaca alQur'an dalam arti melisankan huruf-huruf yang terdapat didalamnya tidak ada gunanya, tetapi merupakan suatu kebaikan, asal sesuai dengan kaidah-kaidah membaca yang berlaku. Sementara itu dalam hal kemampuan menulis terdapat dua pendekatan, yaitu proses dan produk. Setiap siswa pada prinsipnya berbeda baik dari segi kemampuan, minat, kebutuhan, gaya belajar dan sebagainya. Pendekatan proses memandang kegiatan menuis harus dilaksanakan berdasarkan berbedaan tersebut. Hal mana siswa membentuk sendiri topic dan gaya menulis sedangkan pada pendekatan produk siswa diberi rambu-rambu oleh guru.

Menulis bukan hanya aktivitas melukiskan lambang-lambang grafik melainkan proses berpikir. Tulisan dapat menolong manusia dalam melatih dan berpikir kritis. Untuk menumbuhkan budaya menulis siswa pada al-Qur'an dapat dilakukan dengan mengajarkan kepada siswa bagaimana bentuk-bentuk tulisan yang benar. Jadi, baca tulis alqur'an merupakan kegiantan seseorang dalam melisankan serta melambangkan huruf-huruf al-Qur'an. Sementara kompetensi baca tulis al-Quran merupakan kesanggupan seseorang dalam melisankan dan atau membunyikan serta melambangkan huruf-huruf al-Qur'an. Dari pengertian diatas dapat dipahami bahwa pendidikan al-Qur'an merupakan salah satu materi atau bahan pelajaran dalam pendidikan yang lama islam untuk mengarahkan siswa kepada kemampuan membaca, menulis, memahami dan menghayati al-Qur'an untuk menjadikannya sebagai pedoman hidupnya. (Andrian-FITK.pdf.secured.hlm 19)

Metode yang digunakan dalam proses belajar mengajar disesuaikan dengan tujuan yang hendak dicapai. Kemampuan untuk memilih dan menetapkan suatu metode harus memiliki 
guru semenjak awal sehingga tidak salah dalam penggunaan metode tersebut. Pilihan suatu metode sangat bergantung pada : 1).Tujuan yang ingin dicapai pada proses belajar mengajar. 2).Siswa yang belajar, mengenai kemampuan dan latar belakangnya. 3).Guru yang mengajar, mengenai kemampuan dan latar belakangnya. 4).Keadaan proses belajar mengajar. 5).Alat dan sarana yang tersedia. (Depag RI, 1994:85). Pembelajaran Al-Qur'an, metode memegang peranan yang tidak kalah penting dalam komponen-komponen lain. Metode baca dan tulis al-Qur'an adalah suatu cara atau jalan untuk memudahkan pelaksaan pembelajaran Al-Qur'an. Untuk dapat membaca dan menulis AlQur'an seseorang harus terlebih dahulu mengenal huruf-hurufnya, karena tanpanya adalah tidak dimungkinkan bisa membaca ataupun menulis Al-Qur'an. Pada dasarnya, metode yang digunakan dalam pembelajaran Al-Qur'an dibagi dua metodik yaitu, metodik umum dan metodik khusus. Metode khusus meliputi metode Iqra', metode Qa'dah Bagdhadiyyah, dan Qiro'ati. .(AndrianFITK.pdf .secured. 2009:34). Adapun yang termasuk dalam metodik umum adalah:

\section{1). Metode Ceramah}

Metode ceramah atau disebut juga dengan metode mauidzah khasanah merupakan metode pembelajaran yang sangat populer di kalangan para pendidik agama lslam. (Munjin.2013:49). Metode ceramah yaitu cara menyampaikan suatu pelajaran tertentu dengan jalan penuturan secara lisan kepada anak didik atau khalayak ramai. Ciri yang menonjol dalam metode ceramah, dalam pelaksanaan pengajaran dikelas, adalah peranan guru tampak sangat domonan. Adapun murid mendengarkan dengan teliti dan mencatat isi ceramah yang disampaikan oleh guru didepan kelas. . (Yusuf. 1997: 41). Menurut Team Didaktik Metodik Kurikulum IKIP Surabaya (1989: 42), Ceramah Wajar Digunakan:

a). Apabila guru akan menyampaikan fakta (kenyataan) atau pendapatdimana tidak terdapat bahan bacaan yang merangkum fakta atau pendapat yang dimaksud.

b). Apabila guru harus menyampaikan fakta pada siswa yang besar jumlahnya dan karena besarnya kelompok maka metode-metode 
yang lain tidak mungkin dipergunakan.

c). Apabila guru adalah pembicaraan yang bersemangat dan akan merangsang siswa untuk melaksanakan sesuatu pekerjaan.

d). Apabila guru akan menyampaikan pokok yang penting yang telah dipelajari oleh siswa untuk memungkinkan siswa-siswa melihat lebih jelas perhubungan pokok yang satu dengan yang lalu.

Simanjuntak (1986) mencoba merangkum beberapa kelebihan metode ceramah sebagai berikut :

a). Metode ceramah baik digunakan untuk menyampaikan materi yang sulit disampaikan dengan cara lain, seperti menjelaskan makna ayat-ayat al Qur'an dan hadits, persoalan keimanan, juga sejarah keimanan, juga sejarah lslam.

b). Metode ceramah baik untuk memotivasi anak didik dalam mengembangkan minat, hasrat, antusiasme, emosi, dan apreasi terhadap suatu pelajaran.

c). Memberikan keteranganketerangan kepada siswa dalam membantu memecahkan masalah, jika siswa-siswa menghadapi kesulitan-kesulitan.
Darajat (2001) menyatakan bahwa ada beberapa kelemahan dari metode ceramah ini. kelemahan-kelemahan tersebut adalah sebagai berikut:

a). Menjadi perhatian hanya berpusat pada guru sering dianggap anak didik sebagai sosok yang selalu benar. di sini tampak bahwa guru lebih aktif dari pada anak didik.

b). Secara tidak di sadari ada unsure pemaksaan dari guru. karena guru aktif berbicara sedang anak didik hanya pasif mendengar dan melihat apa yang dibicarakan guru, akibatnya anak didik hanya bisa mengikuti alur pikiran guru yang terkadang tidak sejalan dengan alur berpikir mereka.( Nasih, 2013:50-51). Dalam pembelajaran baca tulis AlQur'an metode ini tepat digunakan misalnya jika ingin menerangkan pelajaran mengenai pengertian Tajwid dan lain sebagainya.

(AndrianFITK.pdf.scured.2009:35)

\section{2). Metodologi Latihan (Drill)}

Metode latihan drill merupakan metode pembelajaran yang digunakan untuk memperoleh suatu ketangkasan atau keterampilan dari apa yang telah dipelajari. Dalam pembelajaran pendidikan agama 
Islam, materi yang bisa di ajarkan dengan metode ini diantaranya adalah materi yang bersifat pembiasaan, seperti ibadah sholat, mengkafani jenazah, baca tulis al-Qur'an, dan lain-lain. Secara umum pembelajaran dengan metode latihan (drill) biasanya digunakan agar siswa: (1) memiliki kemampuan motoris/gerak, seperti menghafalkan kata-kata, menulis, dan mempergunakan alat; (2) Mengembangkan kecakapan intelek, seperti mengalikan, membagi, menjumlahkan; dan

Memiliki kemampuan menghubungkan antara sesuatu kedaan dengan yang lain. (Nasih,2013:91). Beberapa keuntungan dalam pemanfaatan metode latihan adalah sebagai berikut:

1). Bahan Pelajaran yang diberikan dalam suasana yang sungguh-sungguh akan lebih kokoh tertanam dalam daya ingatan siswa, karena seluruh pikiran, perasaan, kemauan, dikonsentrasikan pada pelajaran yang dilatihkan.

2). Anak didik akan dapat mempergunakan daya pikirnya dengan bertambah baik, karena dengan pengajaran yang baik maka anak didik akan menjadi lebih teratur, teliti, dan mendorong daya ingatnya.

3). Adanya pengawasan, bimbingan dan koreksi yang segera serta langsung dari guru, memungkinkan siswa untuk melakukan perbaikan kesalahan saat itu juga. Hal ini dapat menghemat waktu belajar disamping itu juga siswa mengetauhi prestasinya.

Disamping kelebihan yang dipunyai, juga ada beberapa kelemahan yang perlu mendapatkan perhatian, yaitu :

1) Latihan yang dilakukan dibawah pengawasan yang ketat dan suasana serius mudah sekali menimbulkan kebosanan.

2) Tekanan yang lebih berat, yang diberikan setelah siswa merasa bosan atau jengkel tidak akan menambah gairah belajar dan menimbulkan keadaan psikis berupa mogok belajar atau latihan

3) Latihan yang terlampau berat dapat menimbulkan perasaan benci dalam diri siswa, baik terhadap pelajaran maupu terhadap guru

4) Latihan yang selalu di berikan dibawah bimbingan guru, perintah guru dapat melemahkan inisiatif maupun kreatifitas siswa.

5) Karena tujuan latihan adalah untuk mengkokohkan asosiasi tertentu, maka siswa akan merasa asing terhadap semua struktur-struktur baru dan menimbulkan perasaan tidak berdaya. (Nasih, 2013:91-92). 


\section{Langkah-langkah Metode Drill}

Dalam pelaksanaanya metode drill terkadang mengalami beberapa hambatan, terutama yang terkait dengan kesiapan guru dan pengkondisian kelas. Oleh karena itu, guru hendaknya memperhatikan beberapa prinsip umum metode drill berikut ini:

1). Siswa harus di beri pengertian yang mendalam sebelum di adakan latihan tertentu.

2). Latihan untuk pertama kalinya hendak bersikap diagnostik:

a. Pada taraf permulaan jangan diharapkan reproduksi yang sempurna.

b. Dalam percobaan kembali harus diteliti kesulitan yang timbul.

c. Respons yang benar harus diperkuat.

d. Baru kemudian diadakan variasi, perkembangan arti dan kontrol.

3). Masa latihan tidak perlu terlalu lama, tetapi harus sering dilakukan.

4). Pada waktu latihan harus dilakukan proses esensial.

5). Latihan yang pertama-tama adalah ketepatan, kecepatan, dan pada akhirnya kedua-duanya harus dapat tercapai sebagai kesatuan.

6). Latihan harus memiliki arti dalam rangka tingkah laku yang lebih luas.
Metode Drill/ latihan siap biasanya digunakan pelajaran-pelajaran yang bersifat motoris seperti: pelajaran menulis, pelajaran bahasa, dan pelajaran keterampilan, dan pelajara-pelajaran yang bersifat kecakapan mental dalam arti melatih anak-anak berpikir cepat. Dalam pembelajaran baca tulis Al-Qur'an, metode ini sering dipakai untuk melatih ulangan pelajaran Al-Qur'an. (AndrianFITK.pdf.scured.2009:37)

\section{3). Metode Tanya jawab}

Metode Tanya jawab ialah penyampaian pelajaran dengan cara guru mengajukan pertanyaan dan murid menjawab. Atau suatu metode di dalam pendidikan di mana guru bertanya sedangkan murid menjawab tentang materi yang ingin di perolehnya.(Armai. 2002:141) Metode tanya jawab berbeda dengan evaluasi. metode Tanya jawab merupakan salah satu teknik penyampaian materi, sedangkan evaluasi adalah alat ukur untuk mengukur hasil belajar siswa.

\section{4). Metode Demonstrasi}

Metode Demonstrasi merupakan metode yang menggunakan paragaan untuk mempeerjelas suatu pengertian atau untuk memperhatikan bagaimana melakukan sesuatu kepada anak didik (Derajat, 2011).

Demonstrasi merupakan metode mengajar 
yang sangat efektif, sebab membantu anak didik untuk mencari jawaban dengan usaha sendiri berdasarkan fakta (data) yang benar. Demonstrasi yang dimaksud ialah suatu metode mengajar yang memperlihatkan bagaimana proses terjadinya sesuatu. Metode demonstrasi ini, dapat diterapkan dalam pembelajaran pendidikan agama Islam khususnya terkait dengan materi keterampilan, seperti praktek membaca al-Quran, shalat, mengkafani jenazah, tayamum dan pelaksanaan haji.( Nasih, 2013:63)

\section{F. Kesimpulan}

a. Autis bukanlah penyakit dan tidak menular

b. Autis karena gangguan pada interaksi sosial, komunikasi, imajinasi, serta pola perilaku yang repetitif (berulang-ulang), dan resistensi (tidak mudah mengikuti/menyesuaikan) terhadap perubahan pada rutinitas.

c. Pendampingan baca tulis Al Qur'an pada anak autis secara tidak langsung mengkombinasikan antara terapi dan metode. Terapi perilaku, visual dan terapi wicara, dimana terapi perilaku untuk memastikan anak tersebut benar sesuai intruksi yang diberikan. Contoh melafalkan alif, maka dia menyebutkan alif secara berulangulang dan guru harus mendampingi dan melafalkan bersama-sama pada posisi berhadap-hadapan.

d. Melalui visualisasi gambar atau huruf nyata, si anak akan melihat dan mengamati antara lafal dan bentuk huruf. Usahakan warnanya yang terang karena mereka sangat respon dengan hal tersebut.

e. Melalui wicara bahwa lidah, mulut serta organ yang berhubungan dengan percakapan melakukan seperti yang diinstruksikan guru / pendamping. Contoh menyebut alif, maka bagaimana memposisikan lidah, bibir dan gigi, kemudian dipatah-patahkan ( A-LIF, FATHHAH, dan seterusnya)

f. Metode pengajarannya dengan metode drill. Karena disitu memuat pengulangan-pengulangan serta pembiasaan-pembiasaan yang bertujuan agar menjadi hal yang melekat pada anak. 


\section{DAFTAR PUSTAKA}

Armai Arief.2002. Pengantar Ilmu dan Metodologi Pendidikan Islam. Jakarta: PT. Intermasa.

Andrian-FITK.pdf.secured.2009.

(online), (http://books.google.co.id), diunduh 27 Februari 2014 7. pukul 10:07 WIB).

Depag RI.1994. Petunjuk Pelaksanaan Kurikulum/GBPP Pendidikan Agama Islam Pada Sekolah Lanjutan Tingkat Pertama Tahun 1994. Jakarta: Dirjend Pembinaan Kelembagaan Agama Islam.

Dudung Abdurohman, Pengantar Metode Penelitian, Yogyakarta, Galang Press 2000

Dunia Psikologi, Autisme,Pengertian dan Defenisisnya. Artikel, september 2011

Galih A Veskariyanti, Terapi Autis Paling Efektif, Pustaka Anggrek. Yogyakarta

Hasibuan, dan Moedjiono.2008. Proses Belajar Mengajar. Bandung: PT Remaja Rosdakarya Offset.

https://barmieny.wordpress.com/2015/ 02/28/pengertian-klasifikasi-dan-

penyebab-autis/

Marlina, Asesmen Pada Anak Berkebutuhan Khusus. Padang: UNP Press, 2009
Nasih, Ahmad Munjin, dan Lilik Nurkholidah. 2013.Metode Dan Teknik Pembelajaran Pendidikan Agama Islam. Bandung: PT Refika Aditama.

Poerwadarminta, W.J.S., Kamus Umum Bahasa Indonesia. Jakarta: Balai Pustaka, 1976

Team Didaktik Metodik Kurikulum IkIP Surabaya, Pengantar Didaktik Metodik Kurikulum PBM.Jakarta : CV. Rajawali., 1989 Yusuf, Tayar, dan syaiful Anwar, Metodologo pengajaran agama dan bahasaarab. Jakarta: PT. RajaGrafindo Persada. 1997 